\title{
Cynaropicrin inhibits lung cancer proliferation by targeting EGFR/AKT signaling pathway
}

\author{
Wenjun $\mathrm{Li}^{1 *}$, Xuechao $\mathrm{Xu}^{2}$, Yixin Wan ${ }^{1}$, Hong Wang ${ }^{1}$, Hongyan Tao ${ }^{1}$, Huirong \\ Huang ${ }^{1}$ \\ ${ }^{1}$ Department of Respiratory Medicine, ${ }^{2}$ Department of General Surgery, Lanzhou University Second Hospital, Lanzhou, Gansu \\ 730000, China \\ *For correspondence: Email: 1454224666@qq.com; Tel/Fax: 0086-0931-8942347
}

\begin{abstract}
Purpose: To investigate the anti-proliferative effect of cynaropicrin on lung cancer cell lines, and the underlying molecular mechanism.

Methods: The effect of cynaropicrin treatment on the viabilities of H1975 and H460 cells was measured using Cell Counting Kit-8. Apoptosis was analysed by annexin-V/FITC staining, while protein expressions were assayed by western blotting.

Results: Treatment of H1975 and H460 cells with cynaropicrin at doses of $0.25-2.0 \mu \mathrm{M}$ led to a marked reduction in their viability ( $p<0.05)$. In cynaropicrin-treated H1975 and H460 cells, there was significant increase in apoptosis, when compared to control cells. Caspase-3 and caspase-9 levels were also significantly increased in $\mathrm{H} 1975$ and $\mathrm{H} 460$ cells on treatment with cynaropicrin at doses of 0.25 and $2.0 \mu \mathrm{M}$ while treatment with cynaropicrin at doses of $0.25-2.0 \mu \mathrm{M}$ significantly down-regulated the $m R N A$ expression of CCND1 in the two cell lines $(p<0.05)$. Cynaropicrin markedly inhibited mRNA and protein expressions of EGFR, and also downregulated AKT in H1975 and H460 cells ( $p<0.05$ ). However, cynaropicrin significantly increased the expressions of miR-202 and miR-370.

Conclusion: Cynaropicrin exerts anti-proliferative and proapoptotic effects on H1975 and H460 lung cancer cells via deactivation of EGFR/AKT signaling pathway. Moreover, it upregulated the expressions of miR-202 and miR-370 in these cells. Thus, cynaropicrin has potentials for the treatment of lung cancer.
\end{abstract}

Keywords: Cynaropicrin, Anti-proliferation, Pro-apoptosis, Caspase-3, Artichoke

\begin{abstract}
This is an Open Access article that uses a fund-ing model which does not charge readers or their institutions for access and distributed under the terms of the Creative Commons Attribution License (http://creativecommons.org/licenses/by/4.0) and the Budapest Open Access Initiative (http://www.budapestopenaccessinitiative.org/read), which permit unrestricted use, distribution, and reproduction in any medium, provided the original work is properly credited.

Tropical Journal of Pharmaceutical Research is indexed by Science Citation Index (SciSearch), Scopus, International Pharmaceutical Abstract, Chemical Abstracts, Embase, Index Copernicus, EBSCO, African Index Medicus, JournalSeek, Journal Citation Reports/Science Edition, Directory of Open Access Journals (DOAJ), African Journal Online, Bioline International, Open-J-Gate and Pharmacy Abstracts
\end{abstract}

\section{INTRODUCTION}

Despite advancements in diagnosis and treatment technologies, lung cancer still remains a leading cause of cancer-related mortalities worldwide $[1,2]$. Poor prognosis of lung cancer is evident in $17 \%$ average 5-year survival of the affected patients [1,2]. Lung cancer is characterized by excessive proliferation potential and rapid metastasis to distant organs [3]. An understanding of the regulatory mechanism involved in lung cancer is important in the development of efficient therapy for the disease. 
MicroRNAs (miRNAs) act as important biomarkers and therapeutic targets for several types of cancers [4]. Various studies have found that the expressions of miR-202 and miR-370 are downregulated in pulmonary carcinoma cells [5-7]. Overexpression of miR-202 leads to arrest of cell cycle, followed by activation of apoptosis through cyclin D1 (CCND1) inhibition in cancer cells [8,9]. Overexpression of miR-202 in pulmonary cancer cells has been associated with inhibition of proliferation through suppression of the expression of signal transducer and activator of transcription (STAT3) $[8,9]$. The tumor inhibitory potential of miR-370 in pulmonary cancer cells is associated with downregulation of epidermal growth factor receptor (EGFR) [7].

Cynaropicrin belongs to the sesquiterpene lactone class of compounds with a 5-7-5 fused tricyclic skeleton [10]. The important pharmacophore believed to be present in cynaropicrin is $y$-butyrolactone ring which is responsible for several biological activities. Cynaropicrin was originally isolated from artichoke (Cynara scolymus L.) [10]. Plants of the artichoke family are known for their significant pharmacological properties and numerous health benefits [10]. Studies have shown that the proliferation of human macrophages such as U937 cells, and Jurkat T leukocyte cells is selectively inhibited by cynaropicrin [11]. It has been reported that the cytotoxicity of cynaropicrin in U937 cells was mediated through arrest of the cell cycle at G1/S phase, followed by apoptosis activation [11]. Subsequently, it was shown that cynaropicrin exhibited pro-apoptotic effect via induction of

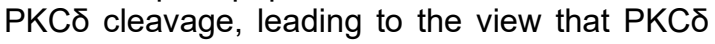
and ROS might be important targets in its antitumor potential [11]. The present study investigated the anti-proliferative potential of cynaropicrin in lung cancer cells, as well as the associated molecular mechanism.

\section{EXPERIMENTAL}

\section{Cell culture}

Lung cancer cell lines (H1975 and H460) were supplied by the American Type Culture Collection (Manassas, VA, USA). The cell lines were cultured at $37{ }^{\circ} \mathrm{C}$ in Dulbecco's modified Eagle's medium (DMEM, Waltham, MA, USA) under $5 \% \mathrm{CO}_{2}$ atmosphere in an incubator. The medium also contained $10 \%$ fetal bovine serum (Gibco; Thermo Fisher Scientific, Inc.) and antibiotics $(100 \mathrm{U} / \mathrm{ml}$ penicillin and $100 \mathrm{mg} / \mathrm{ml}$ streptomycin).

\section{Cell viability assay}

The effect of cynaropicrin (at doses of $0.25-2.0$ $\mu \mathrm{M})$ on the viabilities of $\mathrm{H} 1975$ and $\mathrm{H} 460$ cells was determined using Cell Counting Kit-8 (CCK-8; Inc, Kumamoto, Japan). The cells were seeded in 96-well plates, each at a density at $1 \mathrm{x}$ $10^{5}$ cells/well and incubated with varying concentrations of cynaropicrin $(0.25$ to $2.0 \mu \mathrm{M})$ for $48 \mathrm{~h}$. The incubation was followed by addition of CCK-8 reagent $(10 \mu \mathrm{L})$ to each well. Thereafter, the plates were incubated for additional $2 \mathrm{~h}$ at $37{ }^{\circ} \mathrm{C}$, followed by absorbance reading in a microplate spectrophotometer (SPECTRAMax 190; CA, USA). The readings were used for determination of cell proliferation according to the manufacturer's instructions.

\section{Apoptosis assay}

The cells were grown on coverslips in 6-well plates and treated with cynaropicrin at concentrations of $0.25-2.0 \mu \mathrm{M}$ for $48 \mathrm{~h}$. Thereafter, the coverslips were rinsed with PBS, followed by washing thrice with $1 \mathrm{X}$ binding buffer. Then, the cells were stained with annexin-V/FITC for $40 \mathrm{~min}$ in the dark, and washed with $1 \mathrm{X}$ binding buffer. Finally, the cells were fixed with $2 \%$ formaldehyde for $25 \mathrm{~min}$, and fluorescence values were determined using Olympus-IX71inverted microscope connected to FITC.

\section{Western blot analysis}

Treatment of $\mathrm{H} 1975$ and $\mathrm{H} 460$ cells with cynaropicrin at doses of 0.25 and $2.0 \mu \mathrm{M}$ for 48 $\mathrm{h}$ was followed by lysis using RIPA buffer (50 $\mathrm{mM}$ Tris- $\mathrm{HCl}, \mathrm{pH} 7.4 ; 150 \mathrm{mM}$ sodium chloride and $1 \%$ Nonidet P-40). The lysates were centrifuged at $4{ }^{\circ} \mathrm{C}$ for $20 \mathrm{~min}$ at $13,000 \mathrm{~g}$, and the protein contents of the supernatants were estimated using Bradford method (Beyotime, Haimen, China). Then, 20- $\mu$ g protein samples were resolved on $12 \%$ SDS-polyacrylamide gel electrophoresis, and transferred subsequently to PVDF membranes. Non-specific binding sites in the membranes were blocked by incubation with $5 \%$ skimmed milk at room temperature for 25 $\mathrm{min}$. Thereafter, the membranes were incubated overnight at $4^{\circ} \mathrm{C}$ with the primary antibodies antiCCND1, anti-EGFR, anti-p-AKT, anti-AKT, anticaspase-3, anti-caspase- 9 and anti- $\beta$-actin. After washing the membranes with PBS, they were incubated for $2 \mathrm{~h}$ with horse radish peroxidase-linked secondary antibody at room temperature. Finally, the protein bands were visualized using enhanced chemiluminescence. The protein expressions were normalized to that of $\beta$-actin which served as internal control. 
Reverse transcription-quantitative polymerase chain reaction (RT-qPCR)

Total RNA was extracted from cynaropicrintreated cells using RNAiso Plus (Takara Bio). The RNA extract was reverse-transcribed to complementary DNA (cDNA). The PCR was carried out using $20 \mu \mathrm{L}$ of reaction mixture consisting of $10 \mu \mathrm{l}$ PowerUp ${ }^{\mathrm{TM}}$ SYBR $^{\mathrm{TM}}$ Green Mix, strands of cDNA $(2 \mu \mathrm{l})$ and $1 \mu \mathrm{l}$ of each primer $(10 \mu \mathrm{M})$. The ABI-7300 RT-PCR system (Thermo Fisher Scientific, Inc.) was used for PCR in the following steps: denaturation for 8 min at $94{ }^{\circ} \mathrm{C}$, then 39 cycles for $8 \mathrm{~s}$ at $94{ }^{\circ} \mathrm{C}$, and $59{ }^{\circ} \mathrm{C}$ for $1 \mathrm{~min}$. The PCR signals were normalized with GAPDH, and gene expression levels were calculated using $2^{-\Delta \Delta \mathrm{Cq}}$ method [12].

\section{Statistical analysis}

Data are expressed as mean \pm standard deviation (SD) of three experiments conducted independently. The data were statistically analysed using GraphPad Prism 6.0 (GraphPad Software, Inc, La Jolla, CA, USA). Comparison of the data was made using one-way analysis of variance (ANOVA), followed by Tukey's post-hoc test. Statistical significance was assumed at $p<0.05$.

\section{RESULTS}

\section{Anti-proliferative effect of cynaropicrin on} lung cancer cells

As shown in Figure 1, treatment of $\mathrm{H} 1975$ and $\mathrm{H} 460$ cells with cynaropicrin at doses of 0.25 to $2.0 \mu \mathrm{M}$ led to marked reductions in their viabilities $(p<0.05)$. The viability of $\mathrm{H} 460$ cells decreased more than that of $\mathrm{H} 1975$ cells on treatment with cynaropicrin at doses of 0.25 $2.0 \mu \mathrm{M}$ for $48 \mathrm{~h}$. The treatment with cynaropicrin at doses of 0.25 and $2.0 \mu \mathrm{M}$ decreased $\mathrm{H} 1975$ cell viabilities to 88 and $26 \%$, respectively, while the viability of $\mathrm{H} 460$ cells was suppressed to 84 and $21 \%$, on treatment with 0.25 and $2.0 \mu \mathrm{M}$ cynaropicrin, respectively.

\section{Cynaropicrin induced apoptosis in $\mathrm{H} 1975$ and $\mathrm{H} 460$ cells}

Cynaropicrin significantly induced apoptosis in H1975 and H460 cells, relative to control cells (Figure 2). Treatment with cynaropicrin at doses of 0.25 and $2.0 \mu \mathrm{M}$ increased $\mathrm{H} 1975$ cell apoptosis to 10.54 and $64.32 \%$, respectively at $48 \mathrm{~h}$. In H460 cells, apoptosis increased to 12.08 and $68.65 \%$, on treatment with cynaropicrin at doses of 0.25 and $2.0 \mu \mathrm{M}$, respectively. Moreover, the expression levels of caspase- 3 and caspase- 9 were increased significantly in $\mathrm{H} 1975$ and $\mathrm{H} 460$ cells on treatment with cynaropicrin at doses of 0.25 and $2.0 \mu \mathrm{M}$. These results are shown in Figure 2 .



Figure 1: Effect of cynaropicrin on viabilities of H1975 and $\mathrm{H} 460$ cells. Cynaropicrin treatment at doses in the range of 0.25 to $2.0 \mu \mathrm{M}$ for $48 \mathrm{~h}$ was followed by measurement of cell viability using Cell Counting Kit-8 assay. ${ }^{*} P<0.05 ;{ }^{* *} p<0.01$ vs. control cells

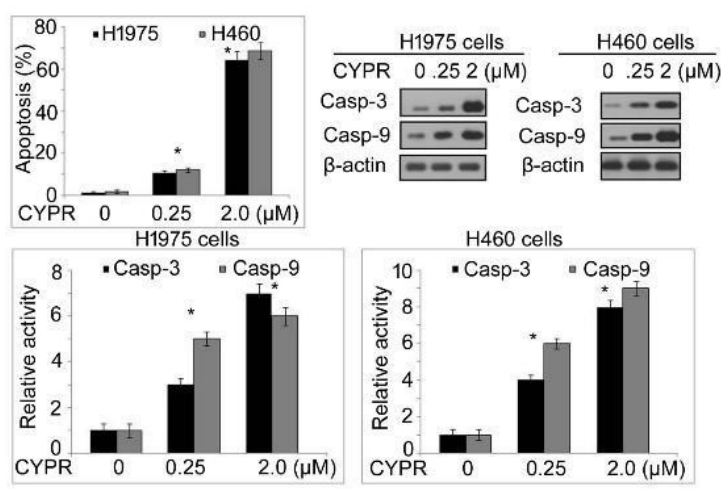

Figure 2: Effect of cynaropicrin on apoptosis of H1975 and H460 cells. Cynaropicrin treatment for 48 $\mathrm{h}$ at doses of 0.25 and $2.0 \mu \mathrm{M}$ was followed by determination of apoptosis using flow cytometry. Caspase protein expression levels were assayed with western blotting. ${ }^{*} P<0.05$, vs. control cells

\section{Cynaropicrin targeted CCND1 expression in lung cancer cells}

In H1975 and H460 cells, cynaropicrin treatment at doses of 0.25 and $2.0 \mu \mathrm{M}$ for $48 \mathrm{~h}$ was followed by assay of CCND1 expression. Cynaropicrin at doses of 0.25 and $2.0 \mu \mathrm{M}$ significantly downregulated mRNA expression of CCNDI in H1975 and $\mathrm{H} 460$ cells $(p<0.05$; Figure 3). The protein expression of CCND1 was also suppressed in H1975 and H460 cells on treatment with 0.25 and $2.0 \mu \mathrm{M}$ cynaropicrin.

\section{Cynaropicrin targeted EGFR expression and p-AKT activation}

The expression of EGFR and activation of $p$ AKT in cynaropicrin-treated $\mathrm{H} 1975$ and $\mathrm{H} 460$ cells were determined after $48 \mathrm{~h}$. Cynaropicrin treatment at doses of 0.25 and $2.0 \mu \mathrm{M}$ 
significantly inhibited the mRNA and protein expressions of EGFR in H1975 and H460 cells. The activation of AKT in H1975 and H460 cells was also significantly suppressed on treatment with 0.25 and $2.0 \mu \mathrm{M}$ cynaropicrin. These results are shown in Figure 4.
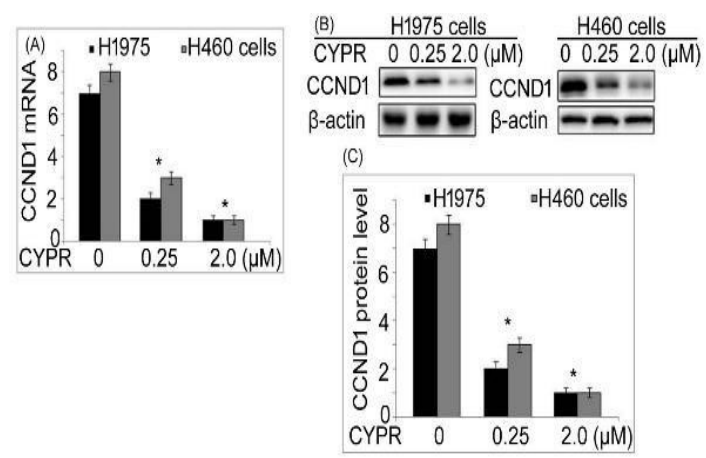

Figure 3: Effect of cynaropicrin on CCND1 expression in $\mathrm{H} 1975$ and $\mathrm{H} 460$ cells. (A) mRNA expression levels of CCNDI after cynaropicrin treatment at doses of 0.25 and $2.0 \mu \mathrm{M}$ for $48 \mathrm{~h}$. (B and C) CCND1 protein expression, as assayed with western blotting. ${ }^{*} P<0.05$ vs. control cells

(A)

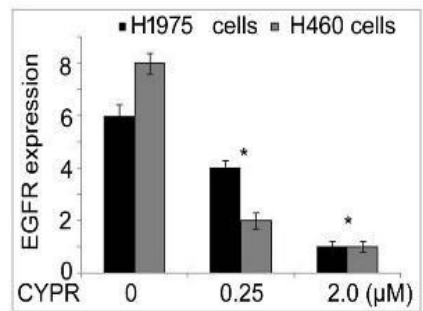

\begin{tabular}{|c|c|c|c|}
\hline (B) & $\mathrm{H} 19$ & $975 \mathrm{c}$ & cells \\
\hline CYPR & 0 & 0.25 & 2.01 \\
\hline EGFR & - & - & - \\
\hline p-AKT & & - & 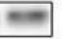 \\
\hline AKT & - & - & - \\
\hline$\beta$-actin & 0 & - & - \\
\hline
\end{tabular}

Figure 4: Effect of cynaropicrin on EGFR expression and AKT activation. (A) mRNA expression of EGFR in $\mathrm{H} 1975$ and $\mathrm{H} 460$ cells exposed to cynaropicrin at doses of 0.25 and $2.0 \mu \mathrm{M}$ for $48 \mathrm{~h}$. (B) Protein expression levels of $\mathrm{p}-\mathrm{AKT}$ and EGFR, as assayed using western blotting. ${ }^{*} P<0.05$ vs. control cells

\section{Cynaropicrin elevated the expressions of miR-202 and miR-370}

The expressions of miR-202 and miR-370 were significantly increased in $\mathrm{H} 1975$ and $\mathrm{H} 460$ cells treated with cynaropicrin at doses of 0.25 and $2.0 \mu \mathrm{M}$ for $48 \mathrm{~h}$ (Figure 5).

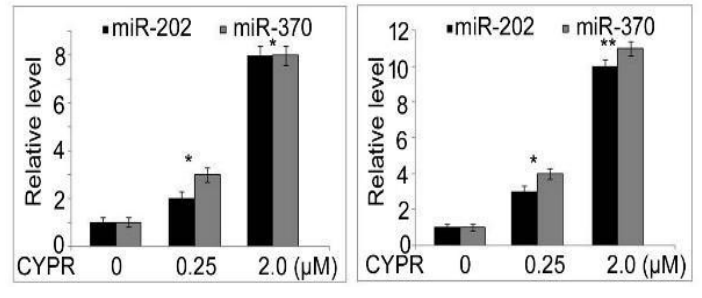

Figure 5: Effect of cynaropicrin on expressions of miR-202 and miR-370. The H1975 and H460 cells were exposed to cynaropicrin at doses of 0.25 and $2.0 \mu \mathrm{M}$ for $48 \mathrm{~h}$, after which miR-202 and miR-370 levels were assayed using RT-PCR. ${ }^{*} P<0.05$ vs. control cells

\section{DISCUSSION}

Cynaropicrin has been shown to selectively target proliferation of human macrophages such as Jurkat T leukocyte cells and U937 cells [12]. It has been reported that the cytotoxicity of cynaropicrin in U937 cells was mediated via arrest of the cell cycle at G1/S phase, and activation of apoptosis [12]. Cynaropicrin exhibits pro-apoptotic effect via induction of PKC $\delta$ cleavage, leading to the idea that PKC and ROS might be important targets for its antitumor potential [12]. In the present study, cynaropicrin induced cytotoxicity against $\mathrm{H} 1975$ and $\mathrm{H} 460$ cells in a concentration-dependent manner. Moreover, the cytotoxicity of cynaropicrin on $\mathrm{H} 460$ cells was greater at all tested concentrations than its toxicity on $\mathrm{H} 1975$ cells. In cynaropicrin-treated $\mathrm{H} 1975$ and H460 cells, apoptosis was increased significantly, relative to the control cells. Moreover, cynaropicrin markedly upregulated the expressions of caspase- 3 and caspase- 9 in H1975 and H460 cells.

Lung carcinogenesis is greatly influenced by the EGFR/AKT pathway which is regulated by some miRNAs [13]. In non-small cell lung carcinomas, miR-133a lowers the activation of AKT and suppresses the expression of EGFR [13]. The miR-145-mediated inhibition of migratory ability and induction of apoptosis of non-small cell lung carcinomas have been linked to downregulation of the EGFR/AKT pathway [14]. In the present study, cynaropicrin treatment of $\mathrm{H} 1975$ and H460 cells led to significant reduction in mRNA and protein expressions of EGFR. Moreover, AKT activation in $\mathrm{H} 1975$ and $\mathrm{H} 460$ cells was downregulated on exposure to cynaropicrin for $48 \mathrm{~h}$. These results indicate that cynaropicrin exhibited cytotoxicity against $\mathrm{H} 1975$ and $\mathrm{H} 460$ cells via downregulation of the EGFR/AKT signaling pathway. 
Studies have demonstrated the tumorsuppressive potential of miR-202, and revealed its downregulation in various types of cancers such as pulmonary cancer, prostate cancer, osteosarcoma and breast carcinomas [8,15-17]. In addition, miR-202 downregulation has been reported in bladder carcinoma tissues and cell lines [17]. Increases in miR-202 levels suppress proliferative capacity, colony forming potential and migratory property [18]. The downregulation of miR-202 has been reported in lung cancer cells, while its over-expression has been shown to increase the sensitivity of the cells to cisplatin via deactivation of Ras/mitogen-activated protein kinase pathway [18]. Similarly, miR-370 downregulation has been reported in pulmonary carcinoma cells, while its overexpression decreased proliferation, colony formation and metastatic potential [7].

In the present study, miR-202 expression was significantly increased in $\mathrm{H} 1975$ and $\mathrm{H} 460$ cells on treatment with cynaropicrin. The cynaropicrin treatment also significantly increased miR-370 levels in $\mathrm{H} 1975$ and $\mathrm{H} 460$ cells. Overexpression of miR-370 led to inhibition of CCND1/CCND kinase pathway in pulmonary carcinoma cells via upregulation of the expression of p21 [7,19]. In the current study, cynaropicrin treatment significantly downregulated mRNA expression of CCNDI in H1975 and H460 cells. The CCND1 protein expression was also suppressed in H1975 and H460 cells on treatment with cynaropicrin.

\section{CONCLUSION}

Cynaropicrin treatment of lung cancer cells produces anti-proliferative and pro-apoptotic effects via deactivation of EGFR/AKT signaling pathway. Furthermore, the expressions of miR-202 and miR-370 are downregulated in H1975 and H460 cells following treatment with cynaropicrin. Thus, cynaropicrin has potential potentials for the management of lung cancer.

\section{DECLARATIONS}

\section{Acknowledgement}

This study was supported by The Scientific Research Project in Gansu Higher Education Institutions (no: 2018B-014).

\section{Conflict of interest}

No conflict of interest is associated with this work.

\section{Contribution of authors}

We declare that this work was done by the authors named in this article and all liabilities pertaining to claims relating to the content of this article will be borne by the authors. Xuechao Xu, Yixin Wan, Hong Wang, Hongyan Tao and Huirong Huang performed the experimental work, carried out the literature survey and analysed and compiled the data. Wenjun Li designed the study and wrote the paper. All the authors read the paper thoroughly and approved it for publication.

\section{Open Access}

This is an Open Access article that uses a funding model which does not charge readers or their institutions for access and distributed under the terms of the Creative Commons Attribution License (http://creativecommons.org/licenses/by/ 4.0) and the Budapest Open Access Initiative (http://www.budapestopenaccessinitiative.org/rea d), which permit unrestricted use, distribution, and reproduction in any medium, provided the original work is properly credited.

\section{REFERENCES}

1. Hao $Y$, Yang $X$, Zhang $D$, Luo J, Chen R. Long noncoding RNA LINC01186, regulated by TGF- $\beta / S M A D 3$, inhibits migration and invasion through Epithelial-Mesenchymal-Transition in lung cancer. Gene 2017; 608: 1-12.

2. Torre LA, Bray F, Siegel RL, Ferlay J, Lortet-Tieulent J, Jemal A. Global cancer statistics, 2012. CA Cancer J Clin 2015; 65: 87-108.

3. Peng J, Chen XL, Cheng $H Z$, Xu ZY, Wang H, Shi ZZ, Liu J, Ning $X G$, Peng $H$. Silencing of KCNK15-AS1 inhibits lung cancer cell proliferation via upregulation of miR-202 and miR-370. Oncol Lett 2019; 18: 5968-5976.

4. Wang Y, Liu Z, Yao B, Li Q, Wang L, Wang C, Dou C, Xu $M$, Liu $Q$, Tu K. Long non-coding RNA CASC2 suppresses epithelial-mesenchymal transition of hepatocellular carcinoma cells through CASC2/miR-367/FBXW7 axis. Mol Cancer 2017; 16: 123.

5. Wang R, Chen XF, Shu YQ. Prediction of non-small cell lung cancer metastasis-associated microRNAs using bioinformatics. Am J Cancer Res 2014; 5: 32-51.

6. Nymark P, Guled M, Borze I, Faisal A, Lahti L, Salmenkivi K, Kettunen E, Anttila $S$, Knuutila $S$. Integrative analysis of microRNA, mRNA and aCGH data reveals asbestos- and histology-related changes in lung cancer. Genes Chromosomes Cancer 2011; 50: 585-597.

7. Chen T, Gao F, Feng S, Yang T, Chen M. MicroRNA-370 inhibits the progression of non-small cell lung cancer by

Trop J Pharm Res, April 2021; 20(4): 719 
downregulating oncogene TRAF4. Oncol Rep 2015; 34: 461-468.

8. Zhao Z, Lv B, Zhang L, Zhao N, Lv Y. miR-202 functions as a tumor suppressor in non-small cell lung cancer by targeting STAT3. Mol Med Rep 2017; 16: 2281-2289.

9. Jiang J, Huang J, Wang XR, Quan YH. MicroRNA-202 induces cell cycle arrest and apoptosis in lung cancer cells through targeting cyclin D1. Eur Rev Med Pharmacol Sci 2016; 20: 2278-2284.

10. Suchy M, Herout V, Šorm F. Terpenes. CXVI. Structure of cynaropicrin. Collect. Czech. Chem. Commun. 1960; 25: 2777-2782.

11. Cho JY, Kim AR, Jung JH, Chun T, Rhee MH, Yoo ES. Cytotoxic and pro-apoptotic activities of cynaropicrin, a sesquiterpene lactone, on the viability of leukocyte cancer cell lines. Eur. J. Pharmacol 2004b; 492: 85-94.

12. Varnholt $H$, Drebber $U$, Schulze F, Wedemeyer I, Schirmacher P, Dienes HP, Odenthal M. MicroRNA gene expression profile of hepatitis $C$ virus-associated hepatocellular carcinoma. Hepatology 2008; 47: 1223-1232.

13. Guo N, Zhao Y, Zhang W, Li S, Li S, Yu J. MicroRNA-133a downregulated EGFR expression in human non-small cell lung cancer cells via AKT/ERK signaling. Oncol Lett 2018; 16: 6045-6050.
14. Li B, Ding CM, Li YX, Peng JC, Geng N, Qin WW. MicroRNA145 inhibits migration and induces apoptosis in human non-small cell lung cancer cells through regulation of the EGFR/PI3K/AKT signaling pathway. Oncol Rep 2018; 40: 2944-2954.

15. Zhang S, Cai J, Xie W, Luo H, Yang F. miR-202 suppresses prostate cancer growth and metastasis by targeting PIK3CA. Exp Ther Med 2018; 16: 1499-1504.

16. Gao S, Cao C, Dai Q, Chen J, Tu J. miR-202 acts as a potential tumor suppressor in breast cancer. Oncol Lett 2018; 16: 1155-1162.

17. Li C, Ma D, Yang J, Lin X, Chen B. miR-202-5p inhibits the migration and invasion of osteosarcoma cells by targeting ROCK1. Oncol Lett 2018; 16: 829-834.

18. Sun W, Ping W, Tian Y, Zou W, Liu J, Zu Y. miR-202 enhances the anti-tumor effect of cisplatin on non-small cell lung cancer by targeting the Ras/MAPK pathway. Cell Physiol Biochem 2018; 51: 2160-2171.

19. Li C, Ge Q, Liu J, Zhang Q, Wang C, Cui K, Chen Z. Effects of miR-1236-3p and miR-370-5p on activation of p21 in various tumors and its inhibition on the growth of lung cancer cells. Tumour Biol 2017; 39: 1010428317710824. 